DOI https://doi.org/10.18551/rjoas.2017-10.01

\title{
CHALLENGES OF LIBERALIZATION: ASEAN ECONOMIC TRADE IN THE CASE OF FARMERS AND REGIONAL GOVERNMENT IN SIDOARJO (EAST JAVA, INDONESIA)
}

\author{
Koesriwulandari*, Wisnujati N.S., Judho D.P. \\ Wijaya Kusuma University, Surabaya, East Java, Indonesia \\ E-mail: wulandari uwks@yahoo.co.id
}

\begin{abstract}
Local governments and farmers throughout Indonesia must be prepared to meet the challenges that come with MEA. This is due to the ratification that the Indonesian government has made to become part of the MEA. The MEA aims to become the basis of primary regional market, as well as becoming the basis of primary regional production. In the end, becoming the MEA aims to develop regions that have the qualities that can compete in the global market, and a proportionate market competitiveness in a regional scale. However in reality, majorities of Indonesian farmers are low-scale and minor farmers with small lands, thus highly prone to fluctuation and changes in the price of agricultural commodity. The question is whether Sidoarjo as the one of the primary region of rice production in Indonesia, and its local government, are prepared to face the challenges that comes with MEA. This research aims to analyze how the local government of Sidoarjo prepares itself for the challenges that comes with MEA. The primary method that is used in this research is the Delphi method; the Delphi method works by collecting experts' opinions these opinions then is used to construct the policies that may be implemented to face the challenges of MEA. In the local government level of Sidoarjo and between the farmers Focus Group Discussion (FGD) was held. This research founds that Sidoarjo in facing the challenges of MEA sets innovative policies to increase food productivity, in particular food-based crop such as rice. This is done by implementing policies such as; Sustainable Farmland Policy (LP2B) written in The Act on Agriculture No. 41 Year 2009, by means of bridging a continuous coordination between the executive and legislative branch; as well as, maintaining the Regional Landscaping Plan (RTRW); assuring the government's special effort (UPSUS) in food selfsufficiency by making reparation in the irrigation system, and production facilities, land optimization, and lastly development of System of Rice by means of intensification. Also, the Movement on Implementation of Integrated Management of Crop (GP-TPP) as well as, the procurement of agricultural machinery and tools (ALSINTA).
\end{abstract}

\section{KEY WORDS}

ASEAN, economic community, government, policy, agriculture, rice.

Building a regional economic strength by creating the ASEAN Economic Community (MEA) trade bloc; enhancing regional trade competitiveness; creating a basis for free-flow goods production, services, investment, capital, skilled labor and to promote regional peace and stability, the block is formed aspiring to create EU-style single market (Asia News Monitor, 2015).

The MEA block of concessions brings consequences for Indonesia, because the MEA bloc expects the establishment of a production base; the realization of a production based can only be done if regional government provides support to food crop agriculture. An example of this can be seen in the State of India. Using technology from the green revolution program that was able to promote a sustainable growth of economic by 4 percent (Lengkap 2014). in Mumbai, India a health card is given to a land used by almost two thousand fertilizer company equipped with soil and seed testing (Lengkap 2017). In Vietnam, the government conducted a dam construction in order to rectify the production of rice in the city of Praja Yedse. Indonesia as the world's fourth most populous country; agriculture plays an important role this is because half of the total employment is agricultural work, and it 
accounts for about a fifth of the Gross Domestic Product, agriculture remains challenging (Syuaib 2016). Policies that can encourage the establishment of agricultural production base in Sidoarjo revolves around the procurement of high yielding and disease-resistant seeds. The policy of agricultural technology implementation is not an arbitrary approach but it is the responsibility of the state in order to minimize losses of trade as well as responding to consumers' demands; increasing public investment in the field agricultural development, furthermore, universities are expected to support the development of agriculture by conducting research as part of the development projects to improve agricultural productivity on certain commodities.

From the descriptions above, the role of the government is significant in order to support agricultural development, next is the issue on how prepared is the local government of Sidoarjo in anticipating the challenges of MEA.

\section{METHODS OF RESEARCH}

Method of Determining Location. The location of this research is chosen purposively (purposive) in the regency of Sidoarjo due to it being one of the regions that produce rice as a commodity in East Java.

Method of Determining Sample. In determining sample for this study, purposive sampling method is used by the researcher; by gathering samples from experts on the field of agriculture such as the Department of Agriculture of East Java, and the Centre for Agricultural Technology Assessment, as well as, the University of Wijaya Kusuma.

Method of Data Retrieval. The Delphi technique is used due to its advantage and capability of a more in-depth data retrieval; where in this instance questionnaire is required to be conducted multiple times. The questionnaire is intended and given to the experts and farmers by means of interview using prepared questions, as well as, Focus Group Discussion (FGD) between the local government and the farmers.

Type of Data. There are two types of data collected, which are: primary and secondary data. In order to collect the primary data, the researcher conducted an interview directly with the respondents; the tool that is present in this activity is questionnaires. The secondary data is collected from the statistics provided by the local statistical institutions and other related institutions (e.g., The Agricultural Department and Service of Sidoarjo and The Office for Food Security).

Method of Data Analysis. By using the Delphi method, which is expected to create solutions for priority development, in readying the farmers' and local government's perception for the effects of MEA.

\section{RESULTS AND DISCUSSION}

There are a few findings that this research has successfully unveil: $A$. The challenges faced by the Regency of Sidoarjo on Development of Food Crop Agriculture, B. Perception of Farmer from the Regency of Sidoarjo towards the Economic Community of ASEAN, and C. Agricultural Development Funding Policy of the Sidoarjo Regency and how it faces ASEAN Economic Community (MEA), lastly, D. The result from the Delphi analysis from the experts.

The challenges faced by the Regency of Sidoarjo on the Development of Agricultural Food crops are as such: a. The narrowing of usable farmland; $b$. The sluggish growth of the Regional Domestic Product Income Growth (GRDP) from the agricultural sector; c. Supporting agricultural facilities and infrastructure, d. Food availability against the result of production within the regency of Sidoarjo; e. The result of production against the consumption rate of Sidoarjo regency; $f$. The recent function switch of Bulog. The results of this research will be further elaborated as followed.

The Narrowing of Usable Farmland. Due to the recent conversion of usable farmland to non-agricultural land (e.g., residential area). The Sustainable Agriculture Farm (LP2B) program is aimed at maintaining food security. The regency of Sidoarjo has provided an area equivalent of 12,206 ha however the government of East Java Province wants those land to 
be used for the preparation of Juanda Airport city in Buduran and Sedati sub-districts. causing the Sidoarjo regency to have only 7,000 hectares of LP2B land. According to research conducted in Tanzania, that results of fragmentation also provides advantages of growing many environmental zones, minimizing production risks and optimizing cropping activities (Reuben et al. 2017)

To support food security in the regency of Sidoarjo a statute may be implemented which is Statute No. 49 of 2009. The only problem is that it cannot be applied in the regency of Sidoarjo, this is due to the lack of personalized data collection of the name and address of the farmer. Again, this is due to the owner of the farmland being outside of the regency of Sidoarjo in the time of data collection, or the farmland is being managed by someone that is not the original owner, furthermore this is exacerbated by the current user of the farmland not knowing the address of the original owner.

Implementation of Statute No.49 of 2009 is still unclear, especially regarding the value of compensation that are received by farmers, this causes farmers to feel at loss. In the District of Buduran more farmers are inclined to sell their land due to it often does generate a substantial amount of profit, in addition the salary that it requires to compensate the workers is quite substantial since many of the workers are brought outside of the regency (e.g., Jombang).

The Growth of GDP within the Regency of Sidoarjo. The picture shows the growth of PDRB Subsector of Agriculture and Husbandry of the regency of Sidoarjo from the year of 2010-2015 (\%).

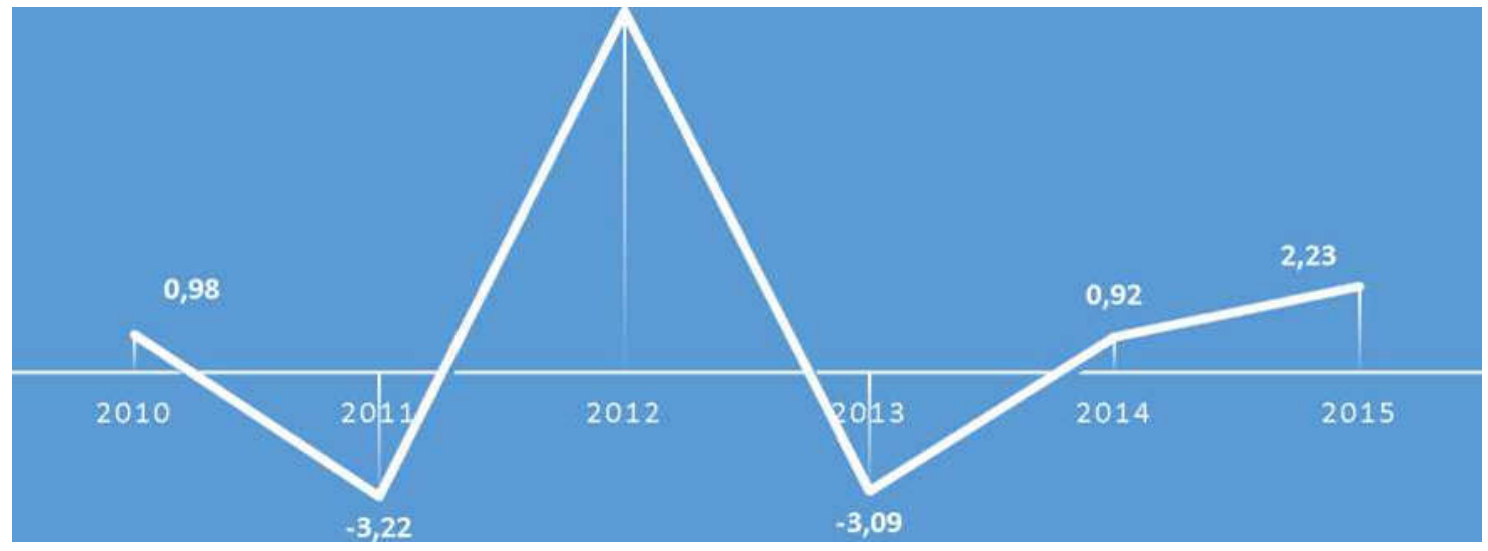

Figure 1 - GDP Growth Subsector Agriculture and Husbandry District Sidoarjo, 2010-2015 (\%) Source: BPS Sidoarjo Regency

GDP growth from the agricultural and livestock subsectors in 2012 to 2015 fluctuates, the largest growth can be seen in 2012 and in 2013 its growth seems to slow down.

In the theory of government expenditure written by Ferry Prasetya (Prasetya 2012) states that every member of the society wants material and spiritual prosperity, and the Government aims to achieve the wishes of society. In northern Romania the position of agricultural sector contribution occupies a secondary position, however the sector appears to support the industry sector. The development of the agricultural sector; increasing the skills of the farmers to better the industry in order to overcome rural poverty (Tefan and Coca 2015).

On the other hand, a research in Nambia shows that the government is responsible for improving the technical and the organizational capacities such as farmers associations, groups, and cooperatives; improving the ability to develop business plans and proper recordings (Zuwarimwe et al. 2014). It is necessary to prepare a roadmap for the development of agriculture through irrigation development, in land development that will become a reference in the implementation of agricultural development of dry land, that can support food self-sufficiency (Pangan, Kemampuan, and Pangan 2015).

Agricultural Facilities and Infrastructure. The regency of Sidoarjo designates several other development priorities besides agriculture (i.e., food crops, fish and shrimp ponds, as 
well as industry) the problem lies in which development should be prioritize. The food crop sector needs enough water for irrigation but other priority is industry. Gedangan sub-district is not expecting any water from the river that flows in the region, so it makes the efforts to control the water nearby abundant source of water. This is as in the case by (Pangan, Kemampuan, and Pangan 2015) that in development of irrigation, it is necessary to formulate a scaffolding prior to the execution of plan.

In the year 2016 a flooding happened that flooded the industrial areas of the regency (District Gedangan, and Tambak area in District Sedati). Learning from this experience, the disaster was caused by an overflow from a river in the Mojokerto regency there was an effort to reduce the flow that leads to Sidoarjo (i.e., from Balongbendo diverted to small river area of Tawangsari with reason for drinking water supply (PDAM), its impact is Sukodono District, sub district of Buduran and lack of water.

Farmers in both areas of the village experienced no obstacles such as the availability of Fertilizers and Seedlings as well as infrastructure issues, not experiencing any water constraints. Farmers in the area also have a way of testing the seeds in which they see the first harvest, if the crops are good they will use the seeds from the first harvest, because they think the seedlings have the resilience and adaptation of the soil in the village area.

The main obstacle in these two villages is damage by attacking pests on the roots of rice commonly called "SUNDEP" damaging the roots and making the dead rice plants. It is also experienced by them when SUNDEP seeding has attacked the prospective rice seedlings.

The obstacles that almost all farmers perceive in these two areas are the value / cost of production and the result is less balanced or almost cuman break event point (behind the capital)

From the results of this study then farmers should be given socialization about the MEA, because the success of development in Sidoarjo regency apart from determined by the government apparatus but also support the public and private (BAPPEDA 2013) in the opinion (Moorthy and Benny 2012) that public opinion is essential to provide legitimacy of the ASEAN integration process.

Availability of Food to Production Results of Sidoarjo Regency. In terms of quantity of production continues to increase, decreased in 2013 increased again in 2014. Food production in Sidoarjo regency when compared with the availability is still low, so the number of food imports from outside the region tends to increase.

Results of Production Against Consuming Needs of Sidoarjo Regency. The following figure describes the results of food production on Consumption needs from Start of 2010 to 2015.

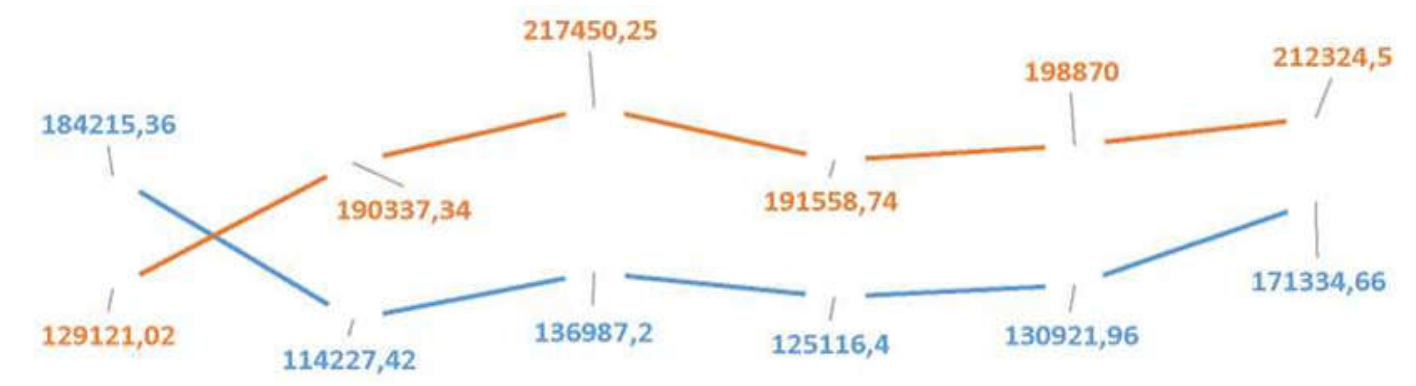

2010

--- Production results --- Consumption needs

Figure 2 - Production Results on Consuming Needs of Sidoarjo Regency, 2010-2015 Source: Food Security Agency of Sidoarjo Regency 
Based on the data above there is a distance between food production to food needs, In the picture shows that consumption is greater than the production it is necessary to meet the consumption of rice from outside Sidoarjo regency. To achieve self-sufficiency in food and the fulfillment of food needs hence the acceleration of food productivity area.

Bulog switch function. Bulog (Agency for Logistics Affairs) Indonesian government established agency usually able to accommodate rice farming during harvest season, but now BULOG switch function is no longer able and willing to buy paddy farmer, this of course make farmer feel confusion, farmer hard sell product, there is a certainty of price and uptake of their production. But the function of BULOG's role started on January 20, 2003 is due to pressure from the community to make BULOG more transparent, and accountable to food policy in particular and government policy in general (Rashid et al. 2008).

Perceptions of Farmers of Sidoarjo Regency in the ASEAN Economic Community. From the results of Focus Group Discussion (FGD) on Farmers In Buduran District Dukuh Tengah Village, Damarsi Village and Sukodono District Cangkringsari Village Gained the fact that farmers do not understand what is meant by the ASEAN Economic Community (MEA), the role of farmers on the liberalization of MEA, socialization of the MEA, assistance given to farmers in facing the MEA and in what year the MEA is signed and implemented.

If on the question of readiness of the farmers with the MEA, they assume MEA no impact for farmers. Annual production results do not experience significant fluctuations. Most of the crops are sold to middlemen and almost all villages in Sidoarjo do not have rice granaries. Types of varieties used are ir 64. Ciherang, commonly used by farmers in the village of middle dukuh and damarsi.

Agricultural Development Funding Policy of Sidoarjo Regency Facing the ASEAN Economic Community (MEA). In Macroeconomic Theory, Government expenditure / local government investment on development aims to improve the welfare of the community. Every member of society wants a material and spiritual prosperity, meaning fulfilled security, justice and prosperity (Prasetya 2012) Expenditure of regional government in agriculture sector will strengthen agricultural development, both in the field of facilities and infrastructure, human resources and credit in the peasant society, investments and government spending have a strategic role.From the results of research Sidoarjo Regency Government uses agricultural investment in equipment and machinery, Irrigation road and land as listed below.

Table 1 - Average Regional Balance Sheet of Sidoarjo Regency Budget 2016 (In Million Rupiah)

\begin{tabular}{|c|c|c|c|}
\hline No & Uraian & Jumlah & Rata Rata Pertumbuhan (\%) \\
\hline 1 & Peralatan dan Mesin & 744.700 & 13,70 \\
\hline 2 & Jalan Irigasi dan Jaringan & 2.500 .373 & 11.15 \\
\hline 3 & Tanah & 2.072 .670 & 5.41 \\
\hline
\end{tabular}

In line with research from Olowoparoku et al about the Government of Nigeria's aid (John et al. 2017) to farmers, research shows that agricultural development undertaken is constrained due to staff shortages, low education, poor supervision, less publicity. Sidoarjo regency also uses government fund allocation for irrigation, this is in line with research from Udama in Negeria (Uduma, Samson, and Mure 2016), Sidoarjo District Government need to be noted that the research results indicate that the policy runs alone or ego sectoral, consistent, overlapping oversight, mandate duplication, improper rice markets and relatively high production costs at the farm level so it is necessary to improve the policy of coordination at the level of government agencies.

Kabupaten Sidoarjo Using funding in the land with an average growth of 5.41 percent, meaning that the PEMDA Sidoarjo is seriously allocating funds on agricultural land.

Productivity of Rice / Rice in Sidoarjo District 2010-2015 ( $k w$ / ha). The following figure describes the achievement of paddy productivity annually from 2010 to 2015 . Based on the figure of achievement each year the productivity of rice tends to increase, in 2010 to 2014 ranged 65-66 kw / ha, and increased in 2015 that is $73.93 \mathrm{kw} / \mathrm{ha}$. 


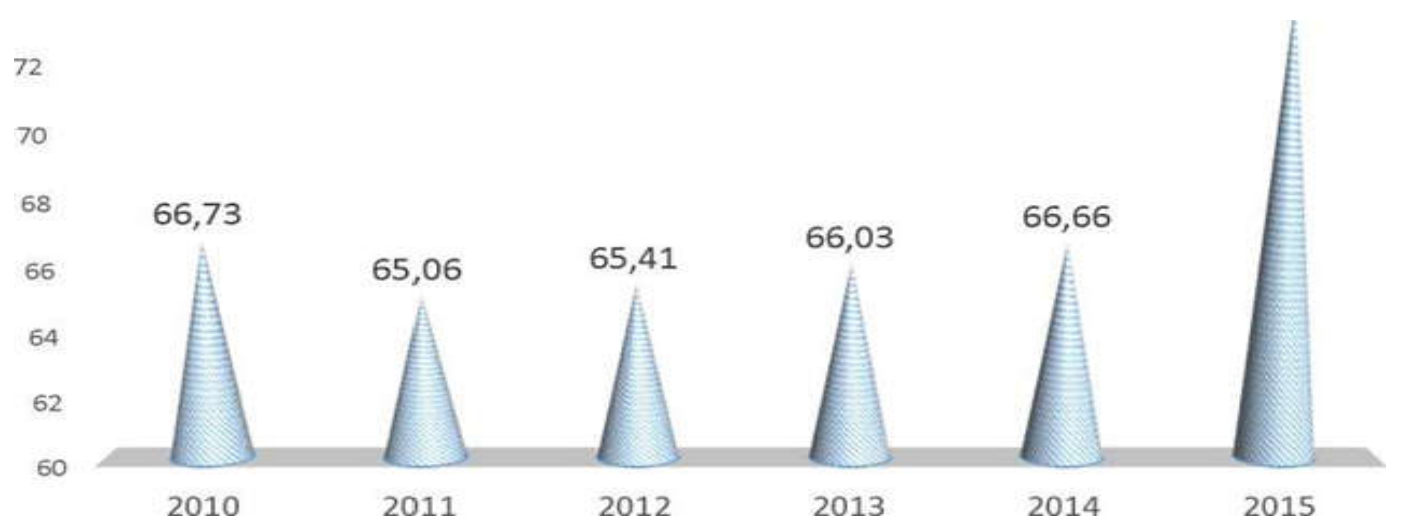

Figure 3 - Productivity of Rice / Rice in Sidoarjo District 2010-2015 (kw / ha)

Sidoarjo in Food Crop Development and Facing MEA. The policy applied in Sidoarjo regency cannot be separated from the policy of the Government above that is East Java Province, Sidoarjo Regency Agricultural Development policy is expected to implement several items, namely:

Irrigation is attempted to use irrigation water optimally;

The cropping index is attempted to increase from $1 \mathrm{x}$ to $2 \mathrm{x}$;

Varieties of seedlings planted are usually relatively long (4 months or 110 days) then it is expected to use varieties aged only 80 days;

Pest prevention in rice crops, conducted spot stop ie pest management by eradicating pests of disease in the area of attack (Spot) and in the stop (this) reduces the cost and efficiency of pesticide use and reduce environmental damage;

Utilizing assistance from East Java Province which aims farmers can make organic fertilizer, the aid is a tool called APPO (organic fertilizer maker). Assistance in channel per Kecamatan each District get 3 tools and, price peralat is Rp. 25.000.000,-;

the question as to whether the aid is useful, because in the study of land size, type of ecosystem, type of soil tillage, education, age and incomes in chemical fertilizers in Nigeria

Improvement of agricultural technology to farmers, to cope with the decline of agricultural production but the problem arises that farmers are not skilled farmers because Sidoarjo regency in particular and generally farmers in East Java have aged. Older farmers will find it harder to operate agricultural technology than young farmers, whereas today's agriculture has been left behind by young farmers.

\section{CONCLUSION}

From the results of research then it can be concluded as follows: inputs on agricultural development such as irrigation, agricultural land needs to be optimized; increasing the application of technology Production needs to combine cropping index in striving to increase from $1 x$ to $2 x$, varieties of seedlings planted relatively short, pest prevention, farmers are able to make organic fertilizer; improvement of agricultural technology to farmers.

\section{ACKNOWLEDGEMENTS}

Thank you to the Minister of Research and Technology (MENRISTEK) of Higher Education (DIKTI) of the State of Indonesia for funding assistance in this Applied Products research grant, which uses funds in fiscal year 2017, with contract number No.08/LPPM/UWKS/V/2017.

\section{REFERENCES}

1. Bappeda. 2013. “Kabupaten Sidoarjo.”: 1-6. http://bappeda.jatimprov.go.id/bappeda/wpcontent/uploads/potensi-kab-kota-2013/kab-sidoarjo-2013.pdf 
2. Ayodeji J. et al. 2017. "Challenges of Oyo State Agricultural Development Program For Rural Farmers in Oyo State , Southwestern Nigeria." 5(1): 8-12.

3. Lengkap, Teks. 2014. "Bioagri Experts Welcome Budget Allocations for Technology, Capacity Building.": 11-12.

4. 2017. "Budget 2016 Focus on Agriculture and Farmers â $€^{\mathrm{TM}}$ Welfare.": 2015-17.

5. Moorthy, Ravichandran, and Guido Benny. 2012. "Is an 'ASEAN Community' Achievable?" Asian Survey 52(6): 1043-66.

6. Pangan, Terhadap Kemandirian, Memperkuat Kemampuan, and Swasembada Pangan. 2015. "Dukungan Pembangunan Irigasi Dan Lahan Kering Terhadap Kemandirian Pangan Nono Sutrisno Dan Nani Heryani": 30-48.

7. Prasetya, Ferry. 2012. "Modul Ekonomi Publik Bagian V: Teori Pengeluaran Pemerintah." Universitas Brawijaya Malang: 1-36.

8. Rashid, Shahidur, Ashok Gulati, Ralph Waldo Cummings, and Ralph Cummings Jr. 2008. "From Parastatals to Private Trade: Lessons from Asian Agriculture.": 253-NaN, 253. http://search.proquest.com/

9. Reuben, M. J. Kadigi et al. 2017. "Land Fragmentation, Agricultural Productivity and Implications for Agricultural Investments in the Southern Agricultural Growth Corridor of Tanzania (SAGCOT) Region, Tanzania." Journal of Development and Agricultural Economics 9(2): 26-36.

10. Syuaib, M. Faiz. 2016. "Sustainable Agriculture in Indonesia: Facts and Challenges to Keep Growing in Harmony with Environment." Agricultural Engineering International: CIGR Journal 18(2): 170-84.

11. Uduma, Bernadette Ugalahi, Olajide Adeoye Samson, and Uhunamure Agbonlahor Mure. 2016. "Irrigation Potentials and Rice Self-Sufficiency in Nigeria: A Review." African Journal of Agricultural Research 11(5): 298-309. http://academicjournals.org/journal/

12. Zuwarimwe, J, M.Y Teweldemedhin, E Nafele, and M Katjiua. 2014. "Comparative Analysis of Small Scale Irrigation Schemes Government Funded and Private Small Scale Community Project in Namibia." Journal of Development and Agricultural Economics 6(3): 59-64. 